Article

\title{
Field Study on the Waterstop of the Rodin Jet Pile Method in a Water-Rich Sandy Gravel Stratum
}

\author{
Chengli Guan $\$ and Yuyou Yang * \\ School of Engineering and Technology, China University of Geosciences, Beijing 100083, China; \\ guanchengli@cugb.edu.cn \\ * Correspondence: yangyuyou@cugb.edu.cn
}

Received: 21 February 2019; Accepted: 19 April 2019; Published: 25 April 2019

check for updates

\begin{abstract}
Due to the increasing depths of underground urban construction, the surrounding environment and hydrogeological conditions are becoming increasingly complex, and conventional high-pressure rotary jet grouting has become unable to meet construction needs. At present, Rodin jet pile (RJP) ultra-high-pressure rotary jet grouting has been widely used as a grouting reinforcement method for deep and large foundations in silty soils, fine sands and clay strata; however, there have been no successful applications in a sandy gravel stratum with high water content (namely, water-rich sandy gravel stratum). Therefore, this paper uses the ventilating shaft in a section of the Beijing Metro as the construction background to carry out field tests on the RJP ultra-high-pressure rotary jet grouting method and waterstop in a water-rich sandy gravel stratum. Through a series of experiments monitoring the formation deformation and pore water pressure and exposing the pile diameter, pile occlusion, pile strength, and permeability of the test pile construction process, it is believed that, for the RJP ultra-high-pressure construction method in a water-rich sandy gravel stratum, reliable jet solidification can occur, the joint between jets can be achieved, the solid strength can reach $10 \mathrm{MPa}$ or higher, and the permeability coefficient can reach $10^{-8} \mathrm{~cm} / \mathrm{s}$. Therefore, RJP ultra-high-pressure rotary jet grouting can be applied as a waterstop method in water-rich sandy gravel stratum.
\end{abstract}

Keywords: RJP; gravel stratum; stratum deformation; solidification strength; permeability

\section{Introduction}

High-pressure rotary jet grouting technology originated in Japan in the early 1970s. The technology is based on the single-tube method invented by Dr. Wataru Nakanishi in Japan and gradually has become the foundation reinforcement technology of various processes, such as the double-tube method and the triple-tube method [1-3]. The technology is guided by the jet theory, and it cuts soil with a high-pressure jet flow (20-40 MPa) and mixes the cement slurry with soil to form cement solidification. Rotary solidification has suitable quality and low permeability, can improve the shear strength and compressive modulus of the soil, and can form a closed waterstop curtain. Therefore, the technology is widely used as a foundation reinforcement and waterstop treatment, and is currently widely used in silty soils, silts, sands, silty clays and other strata [4-6]. However, conventional high-pressure rotary jet grouting technology is limited by the process conditions of the equipment and the swirling depth, which is generally within $30 \mathrm{~m}$ when the pile diameter is in the range from 0.8 to $1.0 \mathrm{~m}$, and the technology mainly relies on the airlift principle to discharge the waste mud from the gap between the drill pipe and the undisturbed soil. As the construction depth increases, the airlift effect increasingly weakens. When the gap is blocked, the pressure in the surrounding layer of the high-pressure nozzle increases, which reduces the efficiency of the jet spray, affects the reinforcement and reliability, and in severe cases, leads to large deformations of the surrounding formation and surface uplift [7]. 
With the acceleration of construction related to urbanization, urban underground spaces have been constructed at gradually increasing depths, and the surrounding construction, underground pipelines, hydrogeological conditions, etc., have become increasingly complex. Conventional high-pressure rotary jet grouting has been unable to meet engineering requirements due to small pile diameters, shallow construction depths, large disturbances to the surrounding environment, and insufficient flows of the high-pressure pumps [7,8]. To meet the needs of an increasingly complex engineering construction environment and deep underground space development, improve construction efficiency and reduce construction costs, scholars have developed a series of ultra-high-pressure rotary jet grouting technologies based on conventional high-pressure rotary jetting [9-12], such as the Rodin jet pile (RJP) method, which has been widely used in soft soil areas such as Shanghai, Tianjin, Hangzhou, Xiamen, Fuzhou and Wuhan; however, there have been no successful cases in gravel strata similar to those in the Beijing area. According to the literature, the RJP method was tested in the superficial strata (within $4 \mathrm{~m}$ below the surface) of Tongxian County, Beijing, in May 1996 [13]. Since then, there has been no relevant experimental research. Therefore, this paper used the ventilating shaft in a section of the Beijing Metro as the construction background to carry out a field test of RJP ultra-high-pressure rotary jet grouting, and a series of tests were conducted, such as the ratio of grouting materials, grouting pressure, grouting pump flow, construction monitoring, solidification compressive strength and permeability, to provide references for design and construction in water-rich sandy gravel stratum.

\section{RJP Construction Method}

\subsection{Process Principle}

The basic principle of the RJP method is the same as that of conventional high-pressure jet grouting. First, a drilling machine is used to make the pilot hole, and a porous drill pipe with a special nozzle is lowered from the pilot hole to the specified depth. The structure of the soil layer is destroyed by an ultra-high-pressure jet stream, the destroyed soil particles and the slurry are remixed and stirred, and a new solid body is formed in the formation after solidification. However, the RJP method uses a secondary cutting method to cut soils with ultra-high-pressure water and compressed air jets, and the ultra-high-pressure cement slurries and compressed air jets of the upper and lower sections are generated by a device installed at the front end of the porous drill pipe; that is, the upper section uses ultra-high-pressure water supplemented with coaxial compressed air for one cutting pass, and the lower section uses an ultra-high-pressure cement slurry supplemented with coaxial compressed air for secondary cutting. The process increases the cutting depth through the secondary cutting pass in the upper cutting section, and the upper cutting space can be used to smoothly discharge the mud, thereby improving the efficiency of the lower nozzle that is spraying mud and ensuring the rotary solid diameter $[7,8,14]$. The RJP method is shown in Figure 1. 


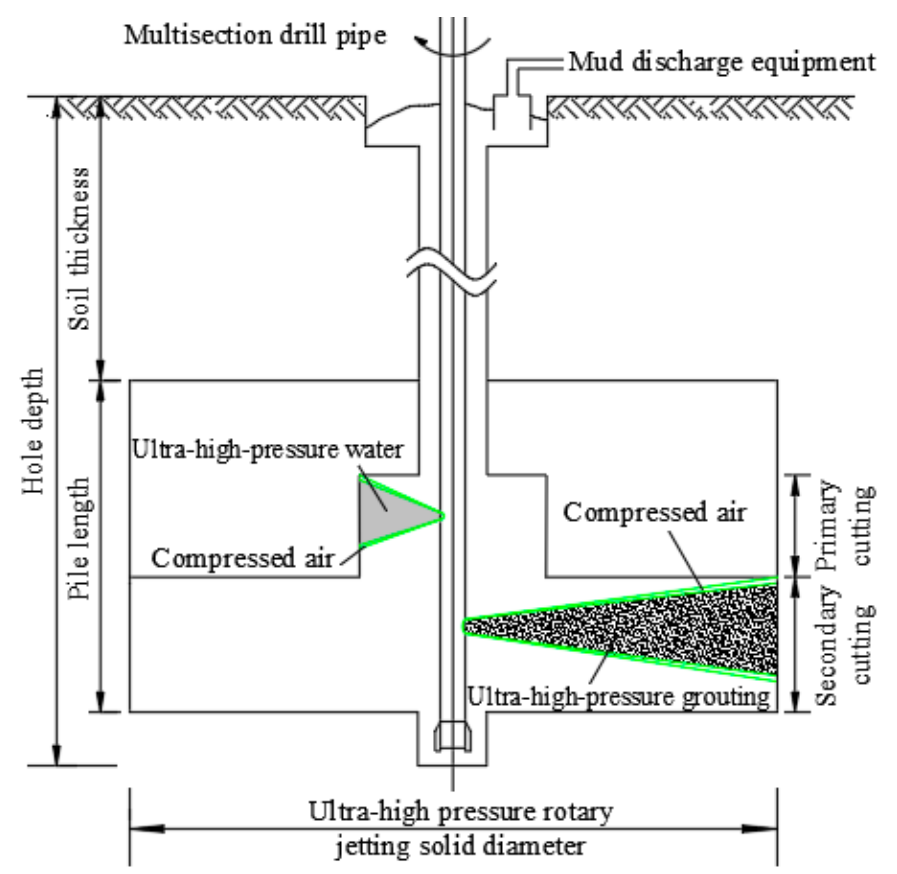

Figure 1. Rodin jet pile (RJP) method concept diagram.

\subsection{Process Characteristics}

1. Large pile depth and large pile diameter

The RJP method can achieve deep foundation improvement, and the maximum depth can reach $60 \mathrm{~m}$. Through the secondary cutting technology, a solid structure with a diameter of 2.0 to $5.0 \mathrm{~m}$ can be realized, while the strength can reach $1.0 \mathrm{MPa}$ or higher, and the permeability coefficient can reach $10^{-7}$ to $10^{-8} \mathrm{~cm} / \mathrm{s}$.

2. Low mud discharge and low displacement

Due to efficiency improvement of the rotary jet, the amount of grouting material is reduced by approximately 20 to $25 \%$ compared with that generated by conventional rotary jet grouting [7], thereby reducing the amount of mud, reducing the environmental impact and reducing the formation deformation by reducing the amount of injection.

3. Shortening the construction period

The RJP method reduces the spray loss rate by using a nozzle with an extremely low frictional resistance and improves the ability to cut into the soil by $10 \%$. The combination of the upper and lower nozzles ensures the diameter of the pile, avoids double spraying, and greatly shortens the construction period.

4. Flexible equipment

The RJP method has the characteristics of miniaturization and a small-diameter drill pipe and can be constructed in a small space or close to a building.

\subsection{Construction Equipment}

The main construction equipment for the RJP method includes a pilot hole drilling machine, a rotary jetting machine, a high-pressure mud pump, a high-pressure water pump, a screw air compressor, a porous drill pipe, a front-end nozzle device, an automatic mixing system, a crane, a water tank, a slurry pump, a mud treatment system and other auxiliary equipment. 


\section{1. $\quad$ Drilling rig}

The drilling machine uses a GYQ-200 series drilling rig, the pilot hole of which has suitable verticality and can be constructed in a space of $4.0 \mathrm{~m}$ or smaller; the construction speed is fast, and the flexibility is suitable.

\section{Rotary spray machine and high-pressure pump}

The rotary jetting machine uses the SI-50S-220 mainframe with a rated power of $30 \mathrm{~kW}$, an SG-150-type high-pressure mud pump with a rated pressure of $40 \mathrm{MPa}$, a flow rate of up to $150 \mathrm{~L} / \mathrm{min}$, suitable stability, etc., and the starting current is low, which can help realize remote control.

3. Porous drill pipe and front-end nozzle device

The RJP method uses a porous drill pipe that relies on the independent operation of each nozzle, which do not affect each other, and mainly includes high-pressure grouting holes, high-pressure air holes, high-pressure water holes, drill pipe connecting holes, etc. The front-end nozzle device primarily influences the upper and lower two-stage mixing nozzle systems, as shown in Figure 2.

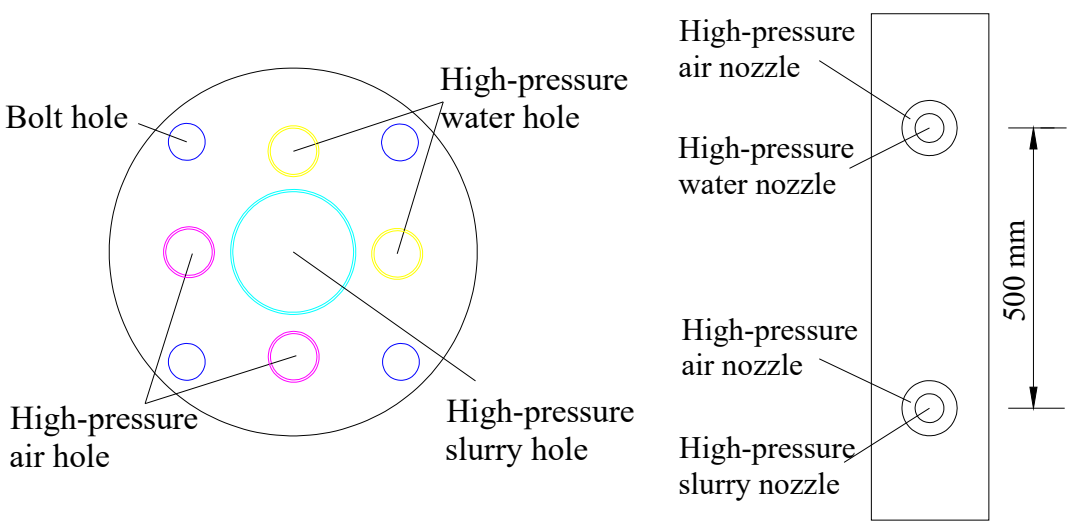

(a)

(b)

Figure 2. (a) Schematic diagram of the porous drill pipe; (b) Schematic diagram of the front nozzle.

\subsection{Factors Affecting the Pile Diameter}

According to a large number of engineering applications, theoretical experiments [15-17], and in particular, the various numerical simulations and field tests of recent years [18-22], it is believed that the standard penetration test numbers $(N)$ and formation cohesion $(c)$ values below have a distinct influence on the effective diameters of the piles, and the effective diameter of the ultra-high-pressure jet grouting method under different soil conditions is summarized [23-25], as shown in Table 1.

Table 1. Effective pile diameter for ultra-high-pressure grouting design under different geological conditions.

\begin{tabular}{cccccc}
\hline Stratum & \multicolumn{5}{c}{ Various Indicator Parameters } \\
\hline \multirow{2}{*}{ Clay } & Soil cohesion $c(\mathrm{kPa})$ & $c<10$ & $10 \leq c<30$ & $30 \leq c<50$ \\
& Effective diameter $(\mathrm{m})$ & 2.4 & 2.2 & 2.0 & \\
\hline \multirow{2}{*}{ Sandy } & Standard penetration $N\left(\mathrm{~N}_{63.5}\right)$ & $N<15$ & $15 \leq N<30$ & $30 \leq N<50$ & $50 \leq N<70$ \\
& Effective diameter $(\mathrm{m})$ & 2.6 & 2.4 & 2.2 & 2.0 \\
\hline \multirow{2}{*}{ Gravel } & \multicolumn{5}{c}{ Not enough data can be referred } \\
\hline
\end{tabular}




\section{Full-Scale Field Test}

\subsection{Test Site}

The test site was a ventilating shaft in Beijing. The length of the ventilating shaft was $48.8 \mathrm{~m}$, the width was $24.4 \mathrm{~m}$, and the depth was $26 \mathrm{~m}$. The shaft was excavated by the open-cut method; thus, the grouting solidification was exposed after the shaft was excavated. The stratum was composed of fill, silt, silty clay, fine sand, and gravel. The groundwater level was $23 \mathrm{~m}$ below the ground. The stratum characteristics and standard penetration were obtained based on laboratory tests. The formation parameters are shown in Table 2.

Table 2. Test site formation parameters.

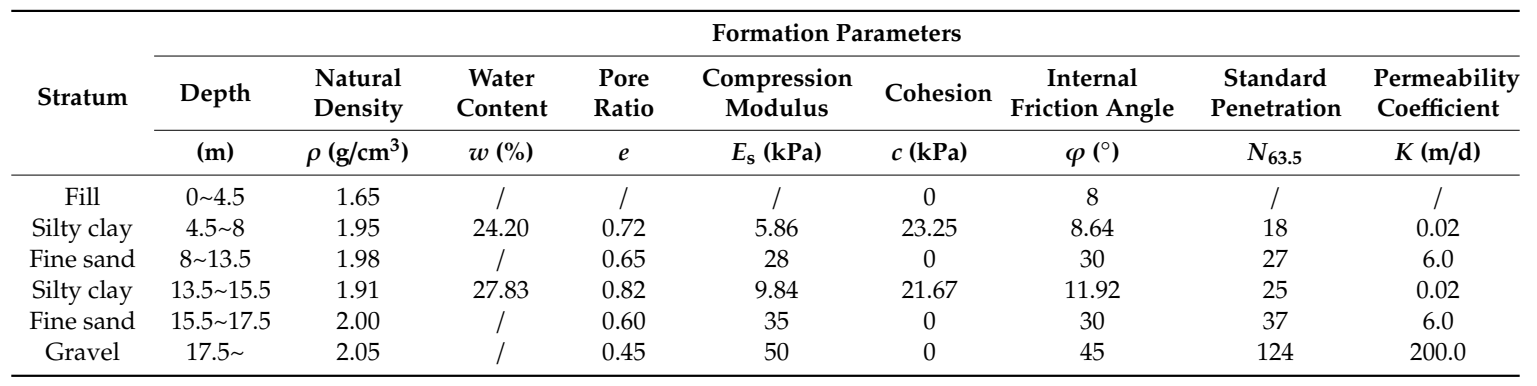

\subsection{Test Plan}

\subsubsection{Test Pile Layout}

In this test, there were three test piles (namely, JP1, JP2, and JP3), the designed pile diameter was $2.0 \mathrm{~m}$, the center distance between the piles was $1.5 \mathrm{~m}$, and the piles were occluded $0.5 \mathrm{~m}$ between the piles (see Figure 3). The designed reinforcement depth was 8.0 to $40 \mathrm{~m}$ below the ground, the effective pile length was $32 \mathrm{~m}$, approximately $2 / 3 \mathrm{rds}$ of the grouting solidification was located below the groundwater level, and approximately $22 \mathrm{~m}$ of grouting solids was located in the gravel stratum.

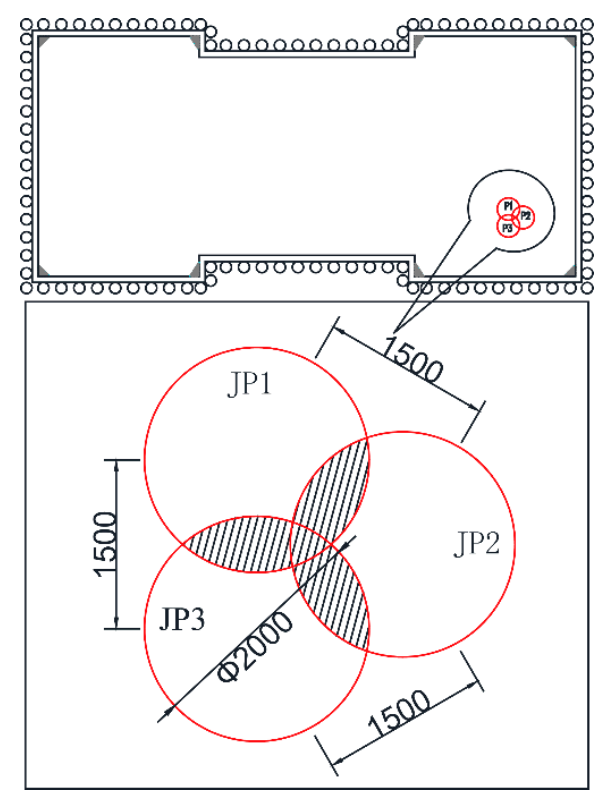

Figure 3. Test pile layout. 


\subsubsection{Construction Parameters}

The construction sequence of the test piles was JP1, JP2 and JP3, and the grouting material was 42.5 grade ordinary Portland cement. According to the formations, the corresponding proportions of bentonite and expansion agent were added, and the equipment consisted of an imported Japanese RJP ultra-high-pressure rotary jet machine and supporting high-pressure grouting pump, high-pressure water pump, air compressor and cement slurry self-mixing system. The ratios of grouting material and equipment construction parameters are provided in Table 3.

Table 3. Grouting material ratios and equipment construction parameters.

\begin{tabular}{|c|c|c|c|c|c|c|c|c|c|c|}
\hline \multirow[b]{2}{*}{ Stratum } & \multirow[b]{2}{*}{$\begin{array}{c}\text { Depth } \\
\text { (m) }\end{array}$} & \multicolumn{3}{|c|}{ Slurry Ratio } & \multirow{2}{*}{$\begin{array}{c}\text { Air } \\
\begin{array}{l}\text { Pressure } \\
(\mathrm{MPa})\end{array}\end{array}$} & \multicolumn{2}{|c|}{ Water } & \multicolumn{2}{|c|}{ Slurry } & \multirow{2}{*}{$\begin{array}{c}\text { Lifting Speed } \\
(\mathrm{cm} / \mathrm{min})\end{array}$} \\
\hline & & $\begin{array}{l}\text { Water-Cement } \\
\text { Ratio }\end{array}$ & Bentonite & $\begin{array}{c}\text { Expansion } \\
\text { Agent }\end{array}$ & & $\begin{array}{c}\text { Flow } \\
\text { (L/min) }\end{array}$ & $\begin{array}{c}\text { Pressure } \\
\text { (MPa) }\end{array}$ & $\begin{array}{c}\text { Flow } \\
\text { (L/min) }\end{array}$ & $\begin{array}{c}\text { Pressure } \\
\text { (MPa) }\end{array}$ & \\
\hline $\begin{array}{l}\text { Fine } \\
\text { sand }\end{array}$ & $8 \sim 13.5$ & $1: 1$ & $15 \%$ & $6 \%$ & $0.7 \sim 0.9$ & $60 \sim 80$ & $34 \sim 36$ & $80 \sim 100$ & $36 \sim 40$ & 4.3 \\
\hline Silty clay & $13.5 \sim 15.5$ & $1: 1$ & $15 \%$ & $6 \%$ & $0.7 \sim 0.9$ & $60 \sim 80$ & $34 \sim 36$ & $80 \sim 100$ & $40 \sim 45$ & 4.3 \\
\hline $\begin{array}{l}\text { Fine } \\
\text { sand }\end{array}$ & $15.5 \sim 17.5$ & $1: 1$ & $15 \%$ & $6 \%$ & $0.7 \sim 0.9$ & $60 \sim 80$ & $34 \sim 36$ & $80 \sim 100$ & $40 \sim 45$ & 4.3 \\
\hline Gravel & $17.5 \sim 40$ & $1: 1.2$ & $20 \%$ & $6 \%$ & $0.7 \sim 0.9$ & $60 \sim 80$ & $34 \sim 36$ & $80 \sim 100$ & $45 \sim 48$ & 3.3 \\
\hline
\end{tabular}

\subsubsection{Monitoring Plan}

The monitoring design mainly consisted of formation deformation monitoring (horizontal displacement of the deep soil and stratified settlement of the surrounding soil) and pore water pressure monitoring. Through the monitoring data, the influence range of the RJP construction process on the surrounding soil disturbance range and grouting pressure was analyzed, and the monitoring points were as follows:

1. There were three monitoring holes for the horizontal displacement of the deep soil. Since the depth of the jet grouting pile ranged from 8 to $40 \mathrm{~m}$ below the ground, considering the difficulty of forming the hole and the unconstructed jet grouting pile from 0 to $8 \mathrm{~m}$ below the ground, the monitoring hole was designed to be fixed at the upper end and free at the lower end, and the depth of the embedded body was $8 \mathrm{~m}$. Each measuring hole had a depth of $18 \mathrm{~m}$, and the order was A, B and C. Measuring hole A was $3 \mathrm{~m}$ from the center of JP3, measuring hole B was $1.5 \mathrm{~m}$ from the center of JP1, and measuring hole $\mathrm{C}$ was $2 \mathrm{~m}$ from the center of JP2. The plane layout is shown in Figure 4.

2. A measuring hole was arranged in the layered settlement point of the soil, which was shared with the horizontal displacement hole $\mathrm{C}$ of the deep soil. A total of 17 measurement points were arranged, and the measurement point spacing was $1 \mathrm{~m}$. The plane layout is shown in Figure 4.

3. The pore water pressure was measured in two measuring holes (namely, P1 and P2). The center distance between measuring hole P1 and JP1 and JP2 was $2 \mathrm{~m}$, and the measurement points were arranged at $10 \mathrm{~m}$ and $24 \mathrm{~m}$ below the ground. Measuring hole P2 was $1.5 \mathrm{~m}$ from the centers of JP1and JP3, and the measurement points were arranged at $21 \mathrm{~m}$ or $32 \mathrm{~m}$ below the ground. The plane layout is shown in Figure 4. A vibrating wire pore pressure gauge was adopted to measure the pore pressure in this study. The pore pressure gauge was buried in the stratum in advance. 


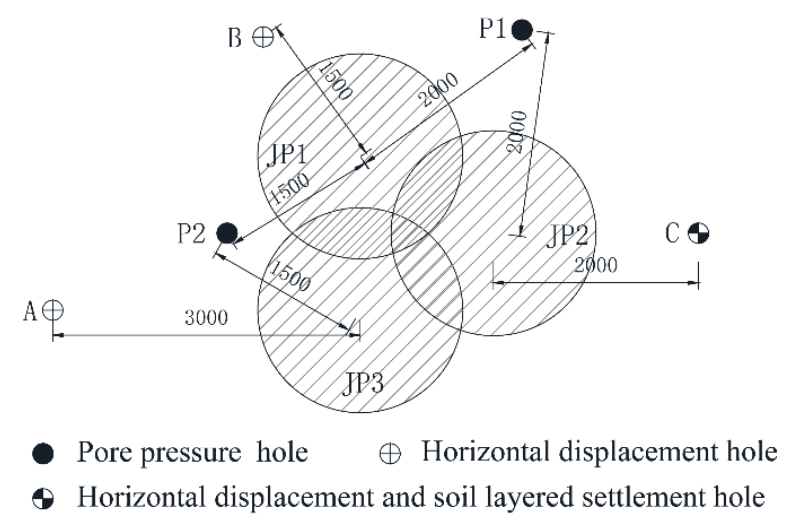

Figure 4. Monitoring point layout.

\subsubsection{Core Sampling}

The samples were cylindrical test pieces with a diameter of $61 \mathrm{~mm}$ and a height of 70 to $100 \mathrm{~mm}$. The samples were taken at the solidification center and occlusions along different elevations; the samples were taken for strength and permeability testing, and the sampling positions are shown in Figure 5.

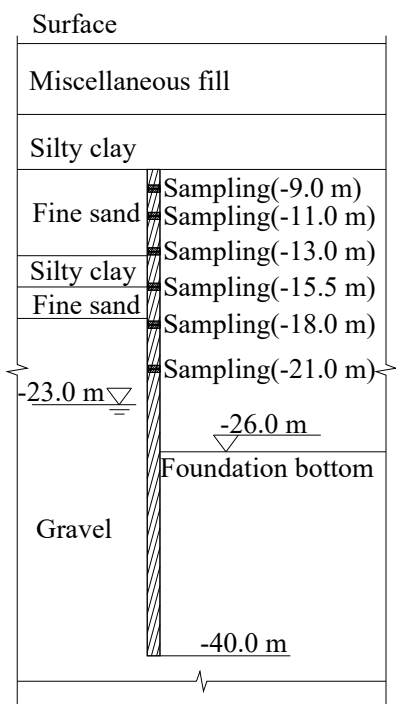

Figure 5. Core sampling layout.

\section{Construction Process}

In this test, there were five monitoring holes and three test piles. The pilot hole was constructed by the GYQ-200 drilling rig and casing follow-up. First, the construction monitoring hole was made, and then the test pile pilot hole and the rotary jet grouting construction were carried out as follows:

1. The construction of the formation deformation monitoring hole started on 21 November 2015 and finished on 25 November 2015. The depth of the formation deformation monitoring hole was $18 \mathrm{~m}$. The depths of the pore water pressure monitoring holes were $24 \mathrm{~m}$ and $32 \mathrm{~m}$.

2. The test pile construction sequence was JP1, JP2 and JP3. The construction of JP1 began on November 27, 2015 and was completed on 30 November 2015. JP2 and JP3 were constructed similarly. The construction of JP2 and JP3 began on 1 December 2015 and was completed on 7 December 2015 (construction process photos are shown in Figure 6). 

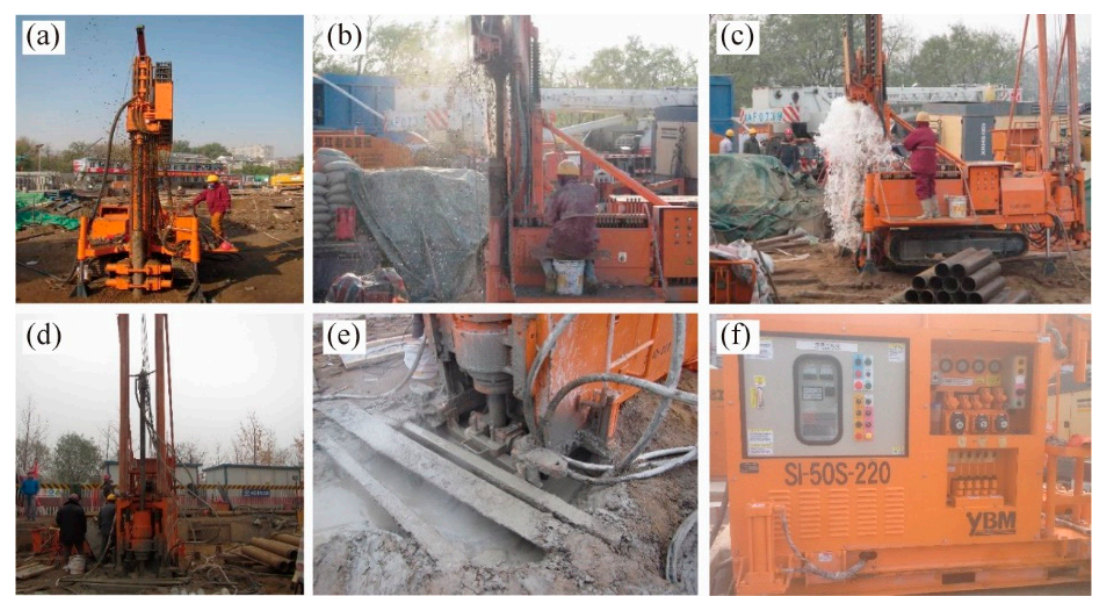

Figure 6. Construction process physical diagram: (a) Drilling into the silty clay stratum; (b) drilling into the gravel stratum; (c) drilling into the groundwater; (d) rotary spray machine construction; (e) rotary spray machine overflow; and (f) rotary spray machine control panel.

The entire field test took 17 days to complete.

\section{Test Results and Analysis}

\subsection{Excavation Disclosure}

With the excavation of the foundation pit, the diameters of the exposed solid structures were as follows:

JP1 was relatively uniform, the pile diameter of the fine sand and clay layers was 1.3 to $1.5 \mathrm{~m}$, and the pile diameter of the gravel layer was approximately $1.6 \mathrm{~m}$.

The diameter of JP2 was 1.0 to $2.3 \mathrm{~m}$, and the variation in the pile diameter was large. The diameter of the fine sand and clay layers was large at the two ends, while the middle was small; the pile diameter at both ends was approximately $2.0 \mathrm{~m}$, and the intermediate pile diameter was approximately $1.6 \mathrm{~m}$. The pile diameter appeared as an awl in the gravel layer: From the top to the bottom of the gravel layer, the pile diameter varied from 2.0 to $1.0 \mathrm{~m}$.

The overall diameter of JP3 was approximately $0.6 \mathrm{~m}$ and reached $1.0 \mathrm{~m}$ only in the fine sand layer.

From the results of the solids analysis, the diameters of the three test piles did not reach the designed pile diameters, and JP1 and JP2 basically achieved occlusion. The majority of JP1, JP2 and JP3 did not achieve occlusion, and the pile diameter and occlusion that were exposed in the different stratum are shown in Figures 7 and 8, respectively.
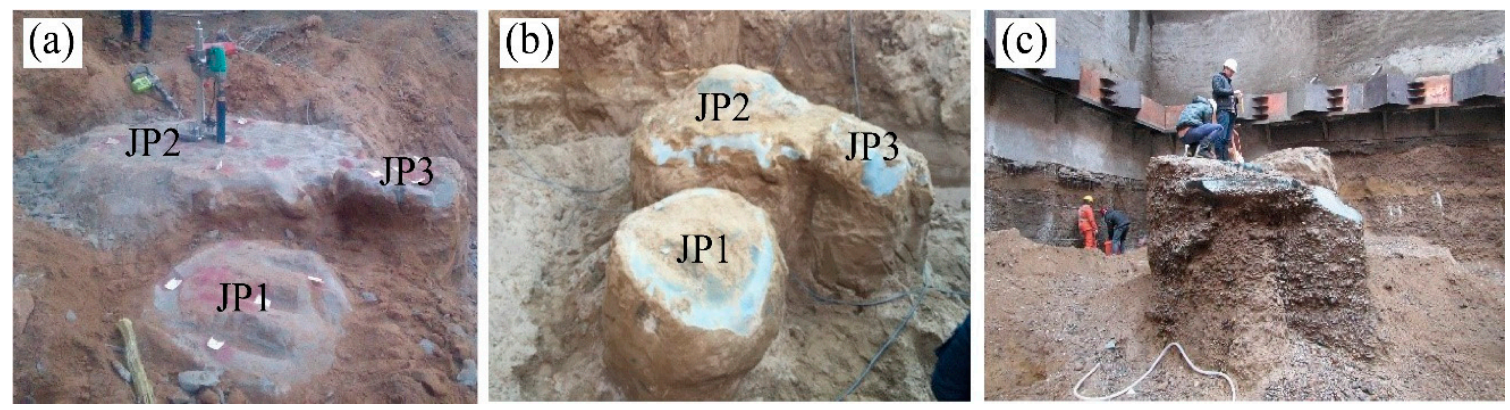

Figure 7. Physical diagram of the excavation: (a) Silty clay stratum pile, (b) fine sand stratum pile, and (c) sandy gravel stratum pile. 


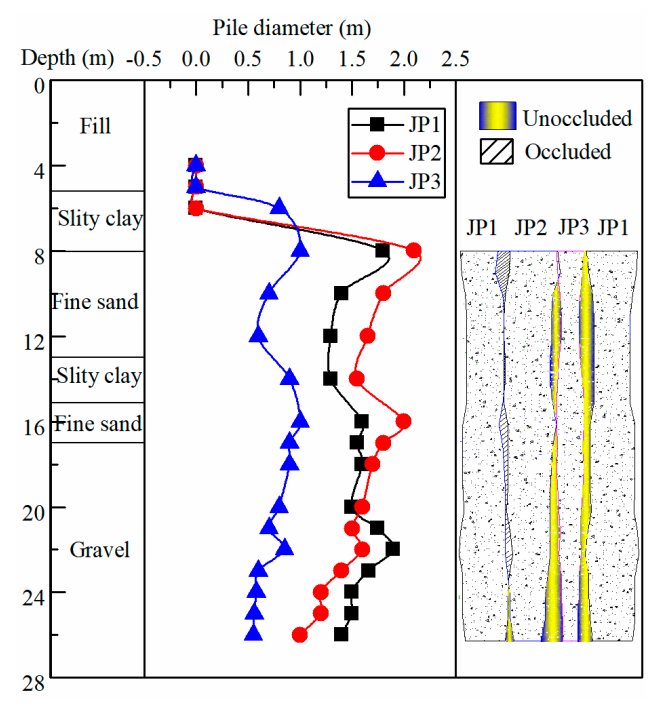

Figure 8. Variation curves and occlusion distributions of the test piles in the different strata.

\subsection{Monitoring Data Analysis}

Monitoring lasted from 28 November 2015 until 7 December 2015. The ground displacement monitoring frequency was twice per day, and the pore water pressure monitoring frequency was four times per day.

\subsubsection{Horizontal Displacement of the Deep Soil}

The horizontal displacements of the strata at different distances were monitored during test pile construction. The monitoring analysis was as follows:

1. The three monitoring points exhibited the same trend: The maximum horizontal displacement of the deep soil occurred from -12 to $-13 \mathrm{~m}$ (the fine sand and silty clay interface), and the cumulative maximum change value was $16.7 \mathrm{~mm}$ (see Figure 9a). The reason may have been that the shear strength of the interface was low and easily destroyed under the action of the ultra-high-pressure shear, resulting in a large change in the horizontal displacement of the formation.

2. The change values of the free ends of the three monitoring holes were small, and the horizontal displacement of the monitoring holes remained almost unchanged as the monitoring holes entered the gravel stratum. The reason may have been that the gravel stratum had large porosity, and under the action of the ultra-high pressure, the slurry and water replaced the fine particles in the pores of the gravel, and the coarse particles in the gravel were not disturbed; hence, the horizontal displacement perturbation was very small.

3. Measurement point A could not be monitored due to the equipment occupancy during construction of JP2. From the monitoring curve analysis of measurement points $B$ and $C$, the cumulative change trend of each measurement point under the construction of JP1, JP2 and JP3 was consistent, but the cumulative growth change value was very small. For example, the horizontal displacement of measurement point $B$ reached $8.9 \mathrm{~mm}$ at a position of $-13 \mathrm{~m}$ during construction of JP1, but the cumulative change values were $9.8 \mathrm{~mm}$ and $10.8 \mathrm{~mm}$ during the construction of JP2 and JP3, respectively, and the variation was very small (see Figure $9 b$ ); the behavior at measurement point $C$ was similar (see Figure 9c). The reason was that JP1 was located between measurement point B and JP2 and JP3. After solidification of JP1, measurement point B was isolated. Therefore, the construction of JP2 and JP3 had little effect on the horizontal displacement of measurement point B. During the construction of JP2, the cumulative value of the horizontal displacement of measurement point $C$ increased greatly, but during the construction of JP3, the cumulative increase in the horizontal displacement was very small. The reason was that JP2 was closest to measurement point $C$ and was located between measurement point $C$ and JP3. Therefore, 
the construction process of JP2 would have the largest influence on the horizontal displacement of measurement point $C$, and the solidification of JP2 occurred; measurement point $C$ was isolated. The construction of JP3 had little effect on the horizontal displacement of measurement point C.

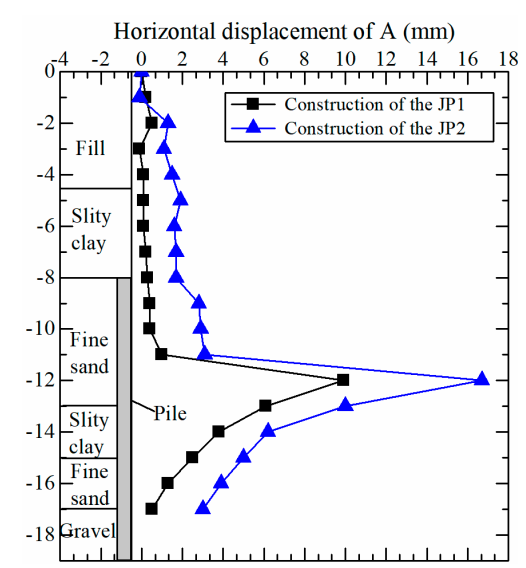

(a)

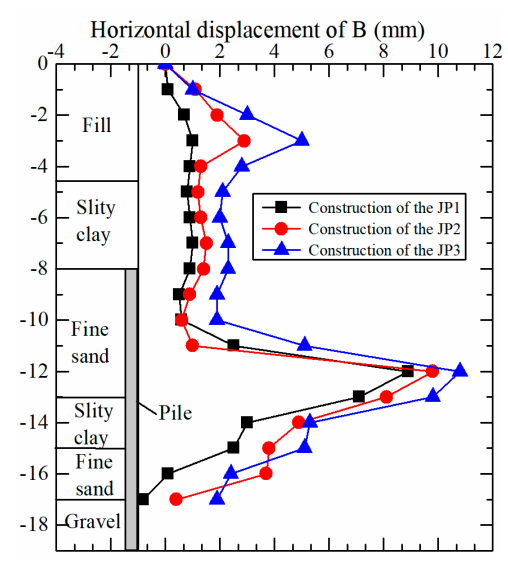

(b)

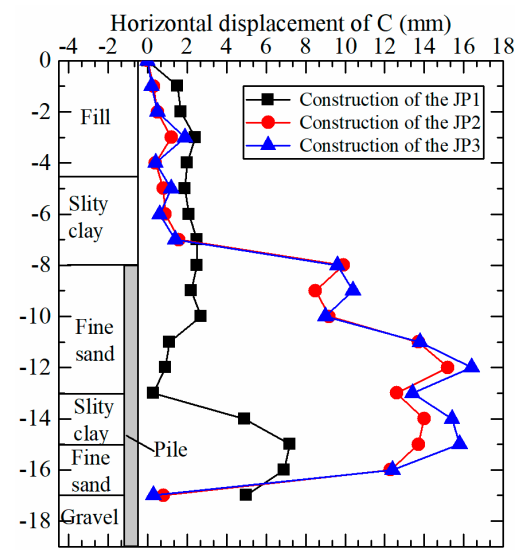

(c)

Figure 9. Horizontal displacement monitoring curves of (a) point $A,(\mathbf{b})$ point $B$, and (c) point $C$.

\subsubsection{Layered Settlement of Soil}

According to the monitoring curve of the layered settlement of the soil, the change trend of the layered settlement curve of hole $C$ during the construction of the three test piles was consistent, soil layered settlement occurred suddenly at -12 to $-13 \mathrm{~m}$ (the interface between the fine sand layer and the silty clay), and the maximum settlement reached $52 \mathrm{~mm}$, indicating that the ultra-high-pressure jet grouting had a certain influence on the interface between the stratum (see Figure 10).

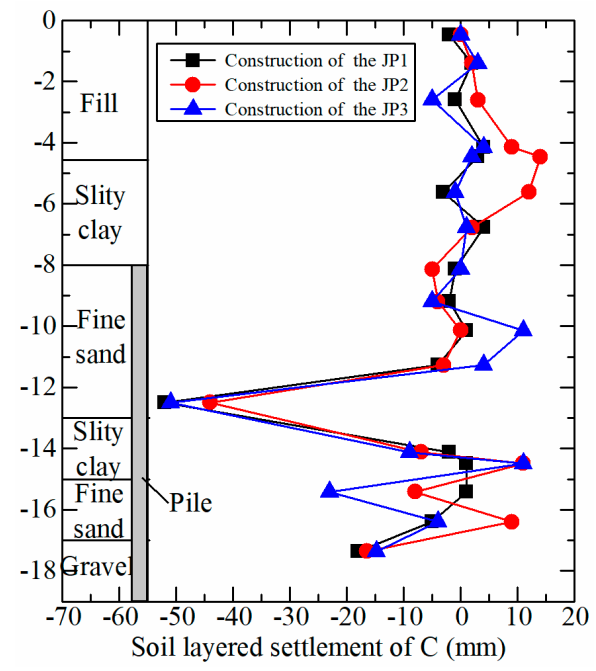

Figure 10. Curve of the cumulative stratified settlement.

\subsubsection{Pore Water Pressure Analysis}

The distance between JP1 and JP2 and the measuring hole P1 was $1.5 \mathrm{~m}$. The distance between JP1 and JP2 and the measuring hole P2 was $2.0 \mathrm{~m}$. The absolute values of the initial pore pressure at positions of $-10 \mathrm{~m}$ and $-24 \mathrm{~m}$ in the measuring hole P1 were $1.5 \mathrm{kPa}$ and $9.8 \mathrm{kPa}$, respectively. The absolute values of the initial pore pressure at positions of $-21 \mathrm{~m}$ and $-32 \mathrm{~m}$ in the measuring hole P2 were $1.8 \mathrm{kPa}$ and $82.6 \mathrm{kPa}$, respectively. The data were collected 12 times from each measuring point during the construction of each test pile. The absolute values of the pore pressure at positions 
of $-10 \mathrm{~m}$ and $-24 \mathrm{~m}$ in the measuring hole P1 were 0.5 to $2.5 \mathrm{kPa}$ and 9.0 to $10.5 \mathrm{kPa}$, respectively. The absolute values of the pore pressure at positions of $-21 \mathrm{~m}$ and $-32 \mathrm{~m}$ in the measuring hole P2 were 1.6 to $2.2 \mathrm{kPa}$ and 82 to $88.4 \mathrm{kPa}$, respectively.

To analyze the influence of slurry pressure on the surrounding stratum, the relative change in pore water pressure was used to analyze the change in pore water pressure during the construction of ultra-high-pressure grouting. Figures 11 and 12 reflect the changes in pore water pressure relative to initial values during construction of JP1, JP2 and JP3. The following results were obtained:

1. In the construction process of JP1, JP2 and JP3, the relative pore pressure at positions of $-10 \mathrm{~m}$ and $-24 \mathrm{~m}$ in the measuring hole P1 was within $1 \mathrm{kPa}$, and the variation was very small (see Figure 11). It showed that the ultra-high-pressure jet grouting did not form excess pore pressure, and the stratum outside the designed pile diameter range was nearly undisturbed during ultra-high-pressure grouting.

2. During the construction of JP1, JP2, and JP3, the relative pore pressure at a position of $-21 \mathrm{~m}$ in the measuring hole P2 was small and was the same as that in the measuring hole P1. However, during construction of JP1, the pore water pressure at a position of $-32 \mathrm{~m}$ changed by 2 to $6 \mathrm{kPa}$ (see Figure 12). It showed that ultra-high-pressure jet grouting caused excess pore water pressure when construction was below the groundwater level.

3. According to the change in pore water pressure, there was a large effect on pore water pressure in the range of $1.5 \mathrm{~m}$ from the center of the pile. However, when the distance was $2.0 \mathrm{~m}$ from the center of the pile, there was little effect of ultra-high-pressure jet grouting.
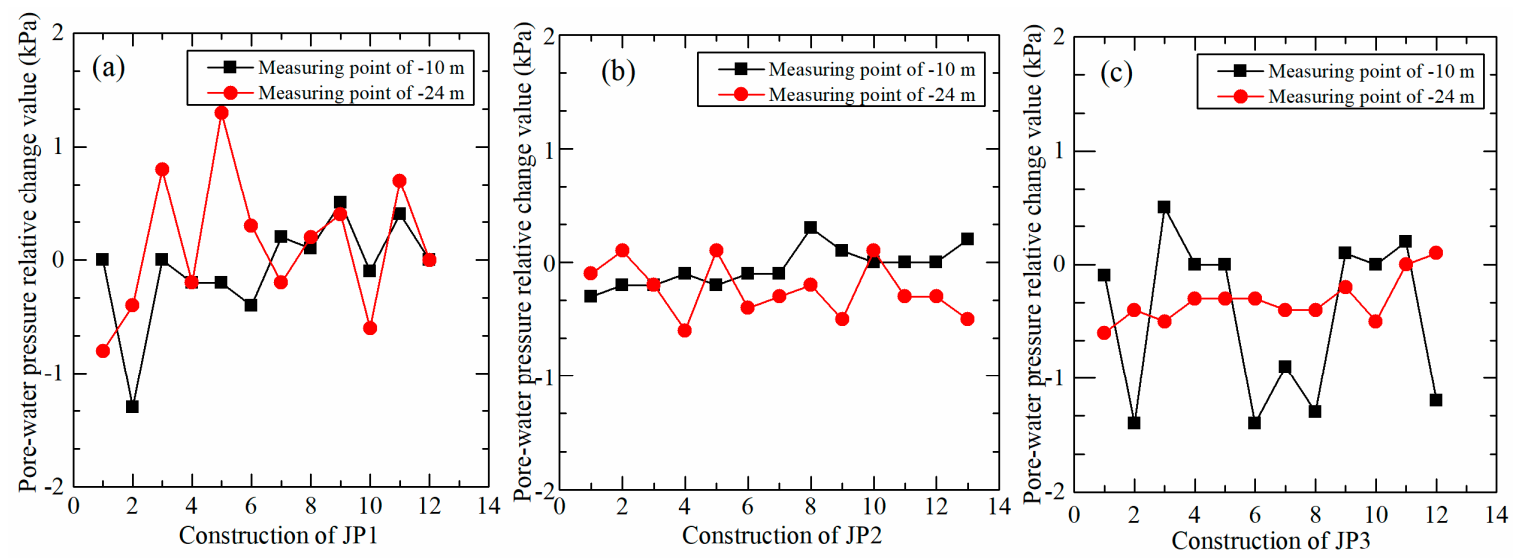

Figure 11. Pore water pressure curve of (a) the construction of test pile 1 (JP1), (b) the construction of test pile 2 (JP2), and (c) the construction of test pile 3 (JP3).
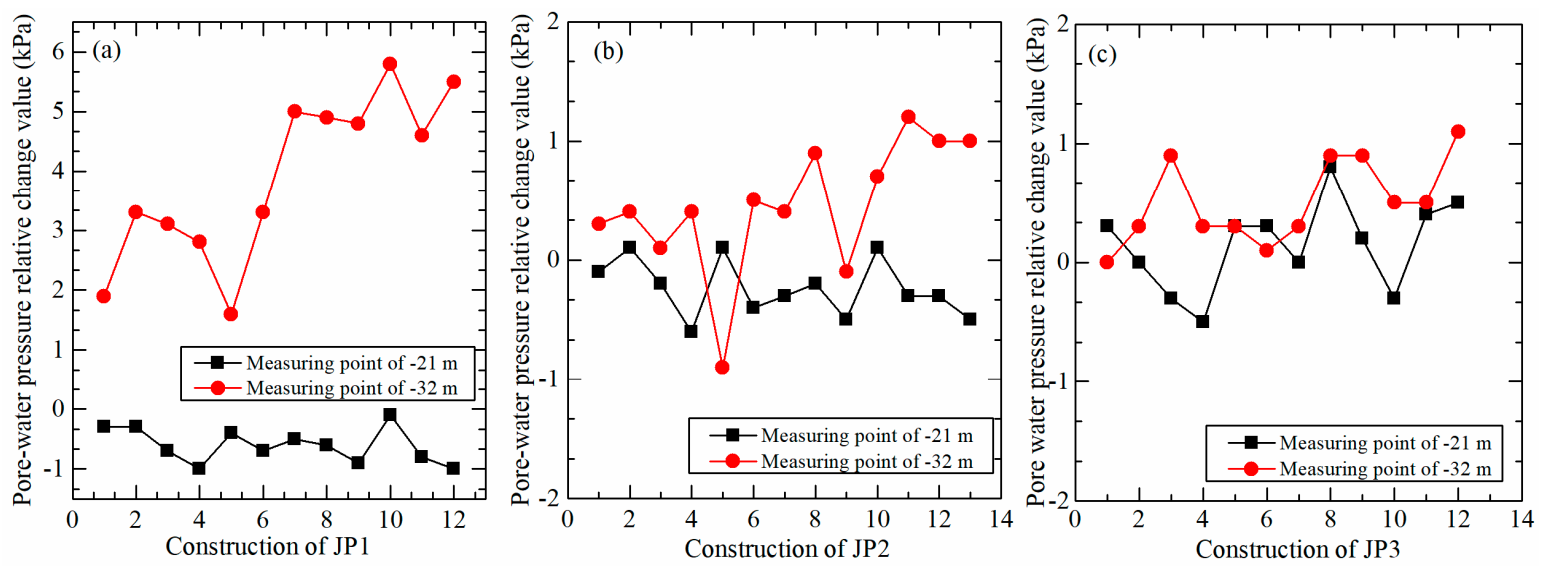

Figure 12. Pore water pressure curve of: (a) Construction of JP1, (b) construction of JP2, and (c) construction of JP3. 


\subsection{Pile Strength and Permeability}

With the excavation of the foundation pit, samples were taken from the fine sand, silty clay and gravel layers. Six sets of compressive strength test specimens and six sets of permeability test specimens were selected from each pile and sent to the laboratory for compressive strength and permeability testing; the test data are shown in Figure 13 and summarized in Table 4. According to the test data, the average compressive strength of the solids in the fine sand layer, silty clay layer and pebble layer were $15.8 \mathrm{MPa}, 12.9 \mathrm{MPa}$ and $32.9 \mathrm{MPa}$, respectively, and the average permeability coefficient of the solids was $10^{-8} \mathrm{~cm} / \mathrm{s}$. The aforementioned factors played an active role in improving the foundation bearing capacity and permeability.

Table 4 . The grouting permeability coefficients obtained from the test.

\begin{tabular}{|c|c|c|c|c|c|c|c|}
\hline \multirow[b]{2}{*}{ Stratum } & \multicolumn{6}{|c|}{ Permeability Coefficient $(\mathrm{cm} / \mathrm{s})$} & \multirow{2}{*}{$\begin{array}{c}\text { Average } \\
\text { Permeability } \\
\text { Coefficient }(\mathrm{cm} / \mathrm{s})\end{array}$} \\
\hline & $\begin{array}{c}\text { Center of } \\
\text { JP1 }\end{array}$ & $\begin{array}{c}\text { Center of } \\
\text { JP2 }\end{array}$ & $\begin{array}{c}\text { Center of } \\
\text { JP3 }\end{array}$ & $\begin{array}{c}\text { JP1 and JP2 } \\
\text { Occlusal }\end{array}$ & $\begin{array}{c}\text { JP1 and JP3 } \\
\text { Occlusal }\end{array}$ & $\begin{array}{c}\text { JP2 and JP3 } \\
\text { Occlusal }\end{array}$ & \\
\hline Fine sand layer & $4.7 \times 10^{-8}$ & $2.1 \times 10^{-8}$ & $1.7 \times 10^{-8}$ & $1.9 \times 10^{-8}$ & $3.4 \times 10^{-8}$ & $7.2 \times 10^{-8}$ & $3.5 \times 10^{-8}$ \\
\hline Silty clay layer & $1.5 \times 10^{-8}$ & $4.4 \times 10^{-8}$ & $5.2 \times 10^{-8}$ & $5.3 \times 10^{-8}$ & $1.8 \times 10^{-8}$ & $1.6 \times 10^{-8}$ & $3.3 \times 10^{-8}$ \\
\hline Gravel layer & $4.1 \times 10^{-8}$ & $3.3 \times 10^{-8}$ & $2.3 \times 10^{-8}$ & $3.6 \times 10^{-8}$ & $1.8 \times 10^{-8}$ & $2.8 \times 10^{-8}$ & $3.0 \times 10^{-8}$ \\
\hline
\end{tabular}

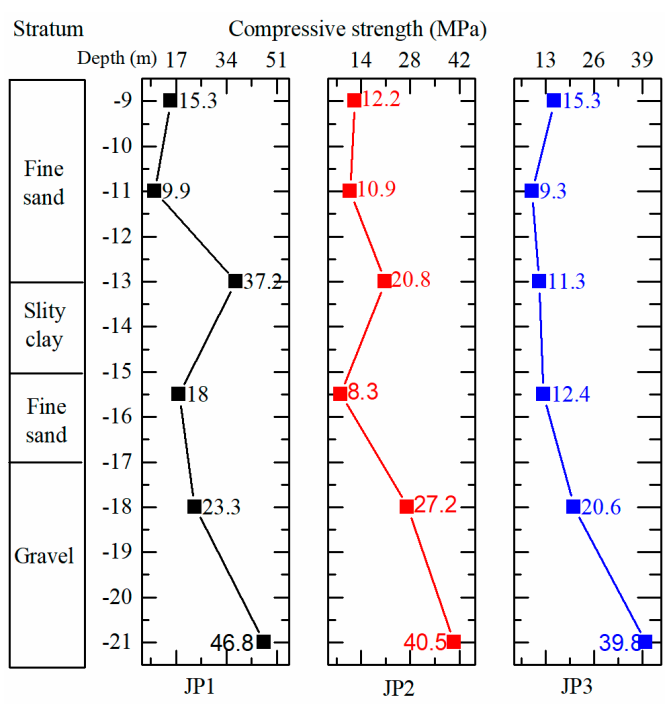

Figure 13. Compressive strength data diagram.

\section{Discussion}

\subsection{Factors Affecting the Diameter of the Jet Grouting Pile}

\subsubsection{Environmental Temperature}

According to the relevant research results [26,27], as the environmental temperature decreases, the cement hydration rate decreases and the cement hydration products, which are lapped and bonded together, are easily precipitated. These factors reduce the fluidity of the cement slurry and increase the friction between the cement slurry and the pipes, causing the cement slurry to lose pressure. This test was performed during winter, and the nighttime temperature was low $\left(-8\right.$ to $\left.-10^{\circ} \mathrm{C}\right)$. The slurry pressure loss was between approximately $3 \mathrm{MPa}$ and $5 \mathrm{MPa}$, and the loss of cement slurry pressure affected the quality of the pile.

\subsubsection{Equipment Failure}

There are two main factors that affected equipment failure. 
First, the nozzle of the drill pipe was frequently blocked, mainly by cement particles or cement hydration products, which means that the jet grouting pile cannot operate continuously. According to the data, the nozzle was blocked for 45 to $50 \%$ of the grouting time, which greatly reduced the effect of jet grouting.

Second, during construction of JP3, the pressure of the ultra-high-pressure grouting pump frequently fluctuated between $35 \mathrm{MPa}$ and $42 \mathrm{MPa}$, and it failed to maintain a constant pressure, which greatly affected the quality of JP3.

\subsubsection{Mechanical Operation}

Because the sandy gravel stratum is very compact, it is very difficult to open. When the lifting speed of the drill pipe is too fast, the slurry does not reach the designed position in a timely manner, which will affect the jet grouting. Therefore, we set a reasonable lifting speed for the drill pipe in the sandy gravel stratum. In this test, a lifting speed for the drill pipe that was too fast could also seriously affect the quality of the pile.

\subsection{Impact of Jet Grouting on the Surrounding Environment}

\subsubsection{Effect of Jet Grouting on the Surrounding Stratum}

According to the monitoring data of the horizontal displacement of the stratum, ultra-high-pressure jet grouting had a slight effect on the horizontal displacement of the surrounding stratum, which was in the range of $3 \mathrm{~m}$ from the center of the pile. Especially at the stratum interface, ultra-high-pressure had a large effect on stratum deformation. However, when the jet grouting was formed, construction on one side of the jet grouting had little influence on the deformation of the other side of the jet grouting, which shows that jet grouting was able to prevent some horizontal deformation of the stratum.

\subsubsection{Effect of the Jet Grouting on Groundwater}

According to the change in pore water pressure, ultra-high-pressure jet grouting will cause excess pore water pressure in the range of $1.5 \mathrm{~m}$ from the center of the pile; therefore, it was necessary to consider the effect of drilling slag during the construction process. When the slag discharge was smooth, the slurry pressure in the hole remained stable, reducing the excess pore water pressure.

\section{Conclusions}

1. RJP ultra-high-pressure jet grouting technology can form a solid with a diameter of approximately $1.5 \mathrm{~m}$ in a water-rich sandy gravel stratum. Its compressive strength reaches more than $10 \mathrm{MPa}$, and the permeability coefficient of the solids reaches $10^{-8} \mathrm{~cm} / \mathrm{s}$, which meets the requirements of foundation excavation. These parameters are reliable for RJP ultra-high-pressure jet grouting construction in the water-rich sandy gravel stratum.

2. The diameter of the jet grouting pile is affected by the compactness of the stratum, the slurry pressure, the lifting speed of the drill pipe, and the environmental temperature. Therefore, it is necessary to be familiar with the characteristics of the stratum and environmental temperature before construction. Then, based on these factors, the mechanical parameters can be set up.

3. The lifting speed of the drill pipe and the slurry pressure should be gradual at the stratum interface, and the construction parameters should not be changed suddenly. In addition, jet grouting has a positive effect on the horizontal displacement resistance of the stratum. Therefore, when jet grouting is carried out over a wide range, construction should be carried out from the outside to the inside to reduce disturbance to the surrounding stratum caused by the ultra-high-pressure jet grouting. 
Author Contributions: Conceptualization, C.G. and Y.Y.; data curation, C.G.; formal analysis, C.G.; investigation, C.G. and Y.Y.; methodology, C.G. and Y.Y.; project administration, C.G. and Y.Y.; writing-original draft, C.G.; writing-review and editing, C.G. and Y.Y.

Funding: This research was funded by the Fundamental Research Funds for the Central Universities, grant number 265201708; the National Nature Science Foundation of China (NSFC), grant number 41472278, and the National Key Research and Development Program of China, grant number 2017 YFC0805008.

Conflicts of Interest: The authors declare that there are no conflict of interest.

\section{References}

1. Shen, S.L.; Wang, Z.F.; Cheng, W.C. Estimation of lateral displacement induced by jet grouting in clayey soils. Geotechnique 2017, 67, 621-630. [CrossRef]

2. Wang, Z.F.; Shen, S.L.; Ho, C.E.; Xu, Y.S. Jet grouting for mitigation of installation disturbance. Proc. Instn Civ. Eng. Geotech. Eng. 2014, 167, 526-536. [CrossRef]

3. Croce, P.; Flora, A. Analysis of single-fluid jet grouting. Geotechnique 2000, 50, 739-748. [CrossRef]

4. Chu, E.H. Fluid-soil interaction model for jet grouting. In Proceedings of the Geo-Denver, Denver, CO, USA, 18-21 February 2007; pp. 1-10.

5. Modoni, G.; Croce, P.; Mongiovi, L. Theoretical modelling of jet grouting. Geotechnique 2006, 56, $335-347$. [CrossRef]

6. Flora, A.; Modoni, G.; Lirer, S.; Croce, P. The diameter of single, double and triple fluid jet grouting columns: prediction method and field trial results. Geotechnique 2013, 63, 934-945. [CrossRef]

7. Hu, X.H.; Kawata, M.; Nakanishi, Y.; Li, J.J. Application of jet grouting pile method in Japan. Chin. J. Geotech. Eng. 2010, 32, 410-413.

8. Zhang, F. Two advanced jet grout methods. Chin. J. Geotech. Eng. 2010, 32, 406-409.

9. Shen, S.L.; Wang, Z.F.; Horpibulsuk, S.; Kim, Y.H. Jet grouting with a newly developed technology: The Twin-Jet method. Eng. Geol. 2012, 152, 87-95. [CrossRef]

10. Shen, S.L.; Wang, Z.F.; Chu, E.H. Current State of the Art in Jet Grouting for Stabilizing Soft Soil. In Proceedings of the Geo-Shanghai, Shanghai, China, 26-28 May 2014; pp. 107-116.

11. Wang, Z.F.; Shen, S.L.; Ho, C.E.; Kim, Y.H. Investigation of field-installation effects of horizontal twin-jet grouting in Shanghai soft soil deposits. Can. Geotech. J. 2013, 50, 288-297. [CrossRef]

12. Njock, P.G.A.; Shen, J.S.; Modoni, G.; Arulrajah, A. Recent Advances in Horizontal Jet Grouting (HJG): An Overview. Arab. J. Sci. Eng. 2018, 43, 1543-1560. [CrossRef]

13. Nakanishi, W.; Nakanishi, Y.; Zhu, Q.L. High pressure jet grouting method-RJP (Rodin Jet Pile) and field practice in Beijing. Chin. Saf. Sci. J. 1997, 7, 35-42.

14. Shen, S.L.; Luo, C.Y.; Xiao, X.C.; Wang, J.L. Improvement Efficacy of RJP Method in Shanghai Soft Deposit. In Proceedings of the U.S.-China Workshop on Ground Improvement Technologies 2009, Orlando, FL, USA, 14 March 2009; pp. 170-178. [CrossRef]

15. Liu, H.L.; Zhou, H.; Kong, G.Q.; Qin, H.Y.; Zha, Y.H. High pressure jet-grouting column installation effect in soft soil: Theoretical model and field application. Comput. Geotech. 2017, 88, 74-94. [CrossRef]

16. Fang, Y.S.; Kao, C.C.; Chou, J.; Chain, K.F.; Wang, D.R.; Lin, C.T. Jet grouting with the superjet-midi method. Ground Improv. 2006, 10, 69-76. [CrossRef]

17. Karahan, G.N.; Sivrikaya, O. Designing singular jet grouting column for sandy soils. Environ. Earth. Sci. 2018, 77, 6280-6299. [CrossRef]

18. Cundall, P.A. A discontinuous future for numerical modeling in Geomechanics. Proc. Inst. Civil Eng. Geotech. Eng. 2001, 149, 41-47. [CrossRef]

19. Chai, J.C.; Carter, J.P.; Miura, N.; Zhu, H.H. Improved Prediction of Lateral Deformations due to Installation of Soil-Cement Columns. J. Geotech. Geoenviron. Eng. 2009, 12, 1836-1845. [CrossRef]

20. Bellato, D.; Schorr, J.; Spagnoli, G. Mathematical Analysis of Shadow Effect in Jet Grouting. J. Geotech. Geoenviron. Eng. 2018, 12, 04018088. [CrossRef]

21. Ochmański, M.; Modoni, G.; Bzówka, J. Prediction of the diameter of jet grouting columns with artificial neural networks. Soils Found. 2015, 55, 425-436. [CrossRef]

22. Modoni, G.; Bzowka, J. Analysis of Foundations Reinforced with Jet Grouting. J. Geotech. Geoenviron. Eng. 2012, 138, 1442-1454. [CrossRef] 
23. Liu, Y.; Pan, Y.T.; Sun, M.M.; Hu, J.; Yao, K. Lateral compression response of overlapping jet-grout columns with geometric imperfections in radius and position. Can. Geotech. J. 2018, 55, 1282-1294. [CrossRef]

24. Toraldo, C.; Modoni, G.; Ochmanski, M.; Croce, P. The characteristic strength of jet-grouted material. Geotechnique 2018, 68, 262-279. [CrossRef]

25. Shen, S.L.; Wang, Z.F.; Yang, J.; Chu, E.H. Generalized approach for prediction of jet grout column diameter. J. Geotech. Geoenviron. Eng. 2013, 139, 2060-2069. [CrossRef]

26. Fan, L.D.; Hu, B.; Shao, H.C. The experimental study on the properties of the cement grout in different temperature. J. Henan Polytech. Univ. Nat. Sci. 2016, 35, 274-280.

27. Yang, J.C.; Ou, Z.W.; Zhong, F.P.; Yu, X.Q. Experimental Study on the Effects of Initial Temperature on Performances of Cement Slurry. Chin. J. Constr. Technol. 2014, 43, 175-177.

(C) 2019 by the authors. Licensee MDPI, Basel, Switzerland. This article is an open access article distributed under the terms and conditions of the Creative Commons Attribution (CC BY) license (http://creativecommons.org/licenses/by/4.0/). 